The opening paragraph of the "Research Manual" is testimony to Mr. Champion's methods-" Research work ought never to be hampered by compulsory adherence to any prescribed methods of investigation or of recording. This does not, however, prevent the research worker from receiving considerable aid from the results of his own experience and that of others". This dictum he illustrated in his "Problem of the Pure Teak Plantation", which included valuable notes supplied by the Forest Research Institute of the Dutch East Indies. Other monographs published were notes on Pinus longifolia; contributions towards a knowledge of twisted fibre in trees; the importance of the origin of seed used in forestry ; rejuvenation and management of sal (Shorea robusta); and a "Manual of Indian Sylviculture" (with Sir Gerald Trevor). In addition to visiting all parts of India and Burma as sylviculturist, Mr. Champion was asked by the Government to advise on the management of the Ceylon forests. He visited North America, Japan and Malaya to study local forest soil conservation problems, and saw something of the Kenya forests on his way home on leave in 1939.

\section{Prof. W. P. Jorissen}

THE Netherlands Chemical Society announced on December 23 that Prof. W. P. Jorissen is retiring from the editorship of the Chemisch Weekblad after serving that journal for thirty years. Although Holland is a small country, it has for many centuries been to the fore in the advancement of science, and Prof. Jorissen, who celebrated his seventieth birthday on November 11, 1939, will rank as one of the country's most distinguished chemists. Since his first paper in 1894 dealing with the oxidation of phosphorus, he and his collaborators have contributed many papers from the laboratory for physical chemistry at the University of Leyden. The most important of these deal with his detailed study of the regions of reactions among gases, and even among solids, and with the physical chemistry of explosions (notably the limits). In addition to his academic and research activities at Leyden, Prof. Jorissen, who is an excellent linguist, was editor-in-chief of the Recueil des travaux chimiques des Pays-Bas as well as of the Chemisch Weekblad. This brought him into lasting contact with the many British chemists who have had occasion to contribute to this Netherlands monthly journal, which publishes communications in French, German and English. We join with his Netherlands colleagues in wishing Prof. Jorissen a long and happy retirement.

\section{Parliamentary and Scientific Committee:}

\section{New Chairman}

Ar the last general meeting of the Parliamentary and Scientific Committee at the House of Commons, Captain L. F. Plugge, M.P., was unanimously elected chairman. Captain Plugge is a science graduate of the University of London and also of the University of Brussels. During the War of 1914-18, when serving with the Royal Naval Air Service, he was the Admiralty representative at the National Physical Laboratory at Teddington. He also served on the directorate of Aeronautical Research at the Air Ministry under Sir Robert Brooke-Popham, when he evolved in collaboration with Dr. Thurston the design of the first military aeroplane constructed entirely in metal to be built in Great Britain. He has been a fellow of the Royal Aeronautical Society since 1923, and was responsible for the Society's glossary of aeronautical terms (French translation). His work on wireless, which has covered the last fifteen years, is well known, and he is an authority on matters relating to broadcasting.

\section{The University of Cracow}

Expressions of sympathy have been received by the Polish Ambassador in Great Britain from universities in Great Britain, the Association of University Teachers and the Universities Bureau of the British Empire in reply to a statement concerning German activities in connexion with the University of Cracow (The Times, Dec. 22). It appears that the members of the teaching staff of the University were invited to attend a conference at which the German attitude toward Polish men of learning was to be explained. The tone of the address offended the audience, who walked out, to find lorries waiting outside, in which they were removed and sent eventually to a concentration camp in Germany.

It is stated that 160 members of the University are involved, including Prof. Kazimierz Kostanecki, a former president of the Polish Academy of Sciences, and Adam Krzyzanowski, a distinguished economist, who has since died. A message from the University of Leeds contains the following passage : "The members of the Senate of the University of Leeds . . . desire to place on record their strong condemnation of an action which can have no military justification and must be regarded as part of a deliberate and wanton attempt to destroy the culture and learning of the Polish peoples." We are sure that readers of NATURE will be in hearty support of this view.

\section{The University of Birmingham}

THE University of Birmingham has settled down to war conditions more smoothly than was anticipated, thanks largely to the recruiting policy of the Government whereby some of the deplorable errors of the War of 1914-18 in the waste of ability of university students have been avoided. The number of students in some departments has actually increased, and in the department of medicine in particular the number of full-time freshmen has reached a total of forty-four more than that of last year. The Nuffield Physics Extension Block is nearly ready for occupation, but the exigencies of war-time have unfortunately interrupted the building of Prof. Oliphant's large cyclotron, which is to be the chief feature of the new block.

The new gymnasium of the University also is nearly complete, and it is hoped that it will be used in the near future for physical training. The plans for extension of the Students' Union have had 
to be dropped for the present. Extra-mural work under the Joint Committee of the University and the Workers' Educational Association has made progress and the number of classes and students has increased. Prof. W. K. Hancock has been given lesve of absence to visit West Africa for a study of West African problems in continuance of his "Survey of British Commonwealth Affairs". Dr. O. Frisch of Copenhagen has been appointed a temporary member of the staff of the Physics Department.

\section{Social Services for Youth}

THE Board of Education has directed attention to a serious deficiency in our social services in a circular recently issued to the local education authorities for higher education in England and Wales, and a similar circular has been issued by the Secretary of State for Scotland to the education authorities in Scotland. These authorities are asked to take steps to set up local youth committees in their areas, and voluntary organizations and education authorities are called upon to combine in making real provision for the social and physical development of young persons between the ages of fourteen and twenty who have ceased full-time attendance at school. This neglected and elusive problem has been accentuated by war conditions- the black-out, the strain and disorganization of family life-and the Board of Education has now assumed a direct responsibility for juvenile welfare. The National Youth Committee has been appointed to advise them and a special branch of the Board of Education office has been organized to deal with grants and other administrative duties.

The new committees will place youth work on an equal basis with the rest of education. Sometimes they will be sub-committees of local authorities; others may represent all local interests including the local authority. Their task will be to work out an ordered policy, meeting both the immediate needs and indicating the lines of advance under more favourable conditions. Local education authorities are expected to see that the Committee is properly staffed and equipped with office accommodation, and they can assist financially by making grants towards the rent of buildings, salaries of full-time leaders, upkeep and maintenance of premises, including provision of equipment and instructors. The appointment of the National Youth Committee has been welcomed by the King in a message to the Prime Minister, in which His Majesty appeals to the public for volunteers to undertake the tasks of leadership and organization which these plans envisage, and an announcement asking for volunteers has already been made by the President of the Board of Education and the Secretary of State for Scotland at the request of the National Youth Committee.

\section{American Psychologists in War-time}

America believes in being forearmed. Already the American Association for Applied Psychology has devised a plan to mobilize psychologists to aid the Government in time of emergency as they did in 1918
(Science Service, Washington, D.C.). The chief problems to be considered are connected with the selecting and classifying of men according to their abilities, the selecting of promising recruits for military flying, treating those who break down under the strain of war and discipline, and keeping up the morale of armed forces and those at home. The human element and human 'nerves' are much more important now than in the War of 1914-18, although even then a considerable proportion of war casualties were 'nervous' cases.

At the meeting which discussed the matter there were representatives of the Army and Navy, the Public Health Service, and the Department of Justice. The armed services have already arranged to avoid in any future war the heavy psychological casualties of the last war. The first step has been to provide for the careful psychiatric examination of all new recruits, with an observation period in which any border-line cases might be weeded out or assigned to jobs where personality difficulties will be at a minimum. They are also discussing whether, by means parallel to those used by enemy agents to foment discord, psychologists could be used to promote good feeling and smooth out grievances.

\section{Aquaria Societies' Difficulties}

THE wartime difficulties of aquaria societies, especially those which maintain public aquaria, have not proved so disastrous as at first expected. The Scottish Aquarium Society, at a recent meeting, decided to produce a modified edition of its journal Scottish Aquarium Herald, as Mr. R. Kerr, the original editor, is serving in H.M. Navy. Brighton Aquarium recently acquired an attractive exhibit of 120 silver whiting (Gadus merl angus), as well as congers, anglers, spider crabs, ocean sunfish and an owl fish. The Carnegie Aquarium at Edinburgh is also managing to keep a full stock of exhibits, including herring. Manchester Zoo Aquarium has 41 specimens of Neon tetra on view in the tropical section, as well as a large electric eel. Dudley (Worcestershire) Zoo Aquarium recently received some claw-footed toads.

On the Continent, Paris Zoo Aquarium has distributed its fish to the Prince of Monaco's Aquarium at Monte Carlo and to private individuals, and its reptiles to Marseilles Zoo. The aquarium at Berlin Zoo has been broken up and closed and the reptiles destroyed. Hamburg Zoo has disposed of all its collection. Belle Vue (Manchester) Aquarium and Vivarium Society has decided to levy half the normal subscription and review the position again in six months' time.

\section{Archæological Discoveries of 1939 in Ireland}

ArCHAOLOGICAL excavations in the vicinity of Lough Gur, Co. Limerick, in the season 1939, it is claimed in a report in The Times of January 2, have obtained results of outstanding significance for Irish archæology. This area has now been under investigation for four consecutive seasons, thanks to the Government's scheme for the relief of unemployment ; 